\title{
Comparison of survival rate and risk of revision for mobile-bearing and fixed-bearing total knee replacements
}

\author{
Hareketli polietilen ve sabit polietilen total diz replasmanları için sağkalım oranı \\ ve revizyon riskinin karşılaştırılması
}

\author{
Marek Lacko, MD, PhD (D), Daniela Schreierová, MD (1) \\ Department of Orthopedics and Traumatology of Locomotors Apparatus, Medical Faculty of Pavol Jozef Safárik University and \\ University Hospital of L. Pasteur, Kosice, Slovakia
}

\begin{abstract}
Objectives: This study aims to determine whether there is a difference in the rate of survival and risk of revision for mobilebearing (MB) compared with fixed-bearing (FB) total knee replacements (TKRs).

Patients and methods: This prospective observational study included 1,571 cemented non-posterior-stabilized TKRs without patellar resurfacing with the subsequent revision surgery in 63 patients (23 males, 40 females; mean age 69.7 years; range, 46.5 to 85.5 years). The group of FB TKRs consisted of 756 non-revised and 31 revised implants. The group of MB TKRs included 752 non-revised and 32 revised knees. We determined the survival rate of TKR with Kaplan-Meier method and the relative risk (RR) of the revision in relation to the type of the insert. The analysis of the RR was divided into subgroups based on the time to revision and the reason for revision.

Results: No significant difference was found between FB and MB TKRs regarding the cumulative survival rate and the RR of total revision for any reasons. In the subgroup of early revisions for any reason, 2.22-fold increased risk of revision was found in the $\mathrm{MB}(\mathrm{p}=0.02)$. The risk of late revisions for any reason in MB was lower than the risk in FB (RR 0.27; $\mathrm{p}=0.009$ ). Higher risk of revision for instability was found in the subgroup of early revisions in $\mathrm{MB}$ ( $\mathrm{RR} 23.8$; $\mathrm{p}=0.03$ ). $\mathrm{MB}$ was associated with significantly lower risk of total (RR $0.46 ; p=0.049)$ and late revisions for aseptic loosening ( $R R 0.14 ; \mathrm{p}=0.008)$.
\end{abstract}

Conclusion: No differences were found in the cumulative survival rates between $\mathrm{MB}$ and FB TKRs. MB TKRs were associated with a lower risk of revision due to aseptic loosening in comparison with FB TKRs. MB inserts represented a significant risk factor only for early revisions due to instability.

Keywords: Fixed bearing, mobile bearing, revision, survival, total knee replacement.
ÖZ

Amaç: $\mathrm{Bu}$ çalışmada hareketli polietilen (HP)'e kıyasla sabit polietilen (SP) total diz replasmanı (TDR)'nda sağkalım oranı ve revizyon riskinde farklılık olup olmadığı belirlendi.

Hastalar ve yöntemler: $\mathrm{Bu}$ prospektif gözlemsel çalışmaya 63 hastada (23 erkek, 40 kadın; ort. yaş 69.7 yıl; dağılım, 46.5-85.5 yıl) takip eden revizyon cerrahisi olan, patella eklem yüzeyi değiştirilmeyen 1571 çimentolu posterior olmayan stabilize TDR dahil edildi. SP TDR grubu 756 revize olmayan ve 31 revize implanttan oluştu. HP TDR grubu 752 revize olmayan ve 32 revize diz içerdi. TDR'nin sağkalım oranı Kaplan-Meier yöntemi ile belirlendi ve revizyonun insert tipine ilişkin göreli risk (GR)'i belirlendi. Göreli riskin analizi revizyon zamanı ve revizyon nedenine dayanılarak alt gruplara ayrıldı.

Bulgular: Sabit polietilen ve HP TDR'ler arasında kümülatif sağkalım oranı ve herhangi bir nedenle total revizyonun GR'si açısından anlamlı farklılık bulunmadı. Herhangi bir nedenle erken revizyon alt grubunda, HP'de 2.22 kat artmıs revizyon riski bulundu ( $\mathrm{p}=0.02)$. HP'de herhangi bir nedenle geç revizyon riski SP'deki riskten daha düşüktü (GR 0.27; p=0.009). HP'de erken revizyon alt grubunda instabilite için daha yüksek revizyon riski bulundu (GR 23.8; p=0.03). HP aseptik gevşeme için anlamlı şekilde daha düşük total (GR 0.46; $\mathrm{p}=0.049$ ) ve geç (GR 0.14; $\mathrm{p}=0.008$ ) revizyon riski ile ilişkiliydi.

Sonuç: Hareketli polietilen ve SP TDR'ler arasında kümülatif sağkalım oranlarında farklılık bulunmadı. SP TDR'lere kıyasla HP TDR'ler aseptik gevşemeye bağlı daha düşük revizyon riski ile ilişkiliydi. HP insertler sadece instabiliteye bağlı erken revizyonlar için anlamlı bir risk faktörü oluşturdu.

Anahtar sözcükler: Sabit polietilen, hareketli polietilen, revizyon, sağkalım, total diz replasmanı.

Received: September 20, 2018 Accepted: October 24, 2018 Published online: June 14, 2019

Correspondence: Marek Lacko, MD, PhD. Department of Orthopedics and Traumatology of Locomotors Apparatus, Medical Faculty of Pavol Jozef Safárik University and University Hospital of L. Pasteur, Kosice, Slovakia. Tel: +42 1556403535 e-mail: marek.lacko@upjs.sk 
Total knee replacements (TKRs) with fixed bearings showed a proven clinical success over several decades of use. However, with the growing trend to perform knee replacements to younger patients with higher functional demands, mobile-bearing (MB) inserts have been introduced in the practice. Mobile-bearing total knee prostheses were designed to provide dualsurface articulation at both the upper and lower surface of the polyethylene insert. These designs would bring a more natural movement and reduced wearing of the polyethylene-bearing insert. This was expected to result in better clinical outcomes and greater survival rate of TKRs.

There is no evidence in the current literature that would clearly confirm theoretical advantages of mobile bearings in the clinical practice. Some reports based on arthroplasty registers even point out the higher risk of revision of TKRs with MB design and have advised caution when selecting such implants. ${ }^{[1-3]}$ Therefore, in this study, we aimed to determine whether there is a difference in the rate of survival and risk of revision of MB compared with fixed-bearing (FB) TKRs.

\section{PATIENTS AND METHODS}

This prospective observational study included 1571 cemented non-posterior-stabilized TKRs without patellar resurfacing performed at University Hospital of L.Pasteur in Košice, Slovakia between January 2002 and June 2018, with the subsequent revision surgery in 63 patients ( 23 males, 40 females; mean age 69.7 years; range, 46.5 to 85.5 years). The study protocol was approved by the University Hospital of L.Pasteur in Košice, Slovakia Ethics Committee. A written informed consent was obtained from each patient. The study was conducted in accordance with the principles of the Declaration of Helsinki.

The selected set of primary TKRs was divided in analysis groups according to the type of bearing insert used in primary TKR (FB or MB insert). All types of inserts allowing a rotational movement at tibia-insert interface of TKR were considered as MB inserts. The group of TKRs with FB insert consisted of 756 implants which did not require revision surgery and 31 implants which were revised in the monitored period. The group of MB TKRs included 752 nonrevised and 32 revised knees.

The FB group consisted of following models of endoprostheses: Anatomically graduated components (AGC) (Biomet, Warsaw, USA; $\mathrm{n}=145$ ), Columbus (B. Braun, Tuttlingen, Germany; $n=443$ ), Sosna-VavříkLandor (SVL) (Beznoska, Kladno, Czech Republic; $\mathrm{n}=199$ ). The MB group included these implants: Columbus (B. Braun, Tuttlingen, Germany; $\mathrm{n}=381$ ), E.Motion (B. Braun, Tuttlingen, Germany; $n=166$ ), Sosna-Vavř́k-Landor/rotating platfond (SVL-RP) (Beznoska, Kladno, Czech Republic; n=237).

The age, gender and body mass index (BMI) of patients, the etiology of osteoarthritis (OA) of the operated knee and the presence of rheumatoid arthritis (RA) and diabetes mellitus (DM) at the time of primary surgery were recorded. If revision surgery of TKR was performed, the time to revision and reason of revision were recorded. The revision of TKR was defined as the reoperation of knee arthroplasty with the replacement, removal or addition of one or more components. ${ }^{[4]}$

The relative risk (RR) of the revision surgery in relation to the type of the insert used in TKR was assessed. The analysis of the risk of revision was divided into three subgroups, based on the time to revision: early revisions, late revisions and total revisions. Early revisions were the revisions performed within five years from the primary surgery (revision $<5$ years). Revision surgeries performed after five years were classified as late revisions (revision surgery $>5$ years). Total revisions were defined as the sum of early and late revisions. The RR was determined for all revision surgeries regardless of the reason for revision (revisions for any reason) and revisions for one of the following reasons: aseptic loosening, periprosthetic infection, instability, femoropatellar pain, periprosthetic fracture, stiffness and allergy to implants.

The survival rate of TKR was determined with the Kaplan-Meier method. The end-point for analysis was revision for any reason.

Multiple logistic regression models were used to evaluate significant predictors of TKR revision for any reason. We analyzed the effect of individual independent variables (use of MB insert; age at the time of primary surgery lower than 55 years; male gender; $\mathrm{BMI}$ higher than $40 \mathrm{~kg} / \mathrm{m}^{2}$; post-traumatic $\mathrm{OA}$; associated disorders - RA and DM) on the observed event, i.e. dependent variable - revision surgery of TKR.

The data for analysis were collected from the medical documentation and reports from national arthroplasty register.

\section{Statistical methods}

Student t-test was used for statistical analysis of continuous variables. If the files had an abnormal distribution, the Mann-Whitney test was used for 
TABLE I

Demographics of non-revised group of primary total knee replacements

\begin{tabular}{|c|c|c|c|c|c|c|c|}
\hline & \multicolumn{3}{|c|}{$\mathrm{MB}(\mathrm{n}=752)$} & \multicolumn{3}{|c|}{ FB $(n=756)$} & \multirow[b]{2}{*}{$p$} \\
\hline & $\%$ & Mean & Range & $\%$ & Mean & Range & \\
\hline Follow-up period (month) & & 99.9 & $12-186$ & & 97.9 & $12-190$ & $0.43^{*}$ \\
\hline Age of patients (year) & & 67.9 & $46-82$ & & 68.9 & $44-84.5$ & $0.63 \dagger$ \\
\hline BMI of patients $\left(\mathrm{kg} / \mathrm{m}^{2}\right)$ & & 31.0 & $22.4-42.9$ & & 31.2 & $20.4-44$ & $0.6^{*}$ \\
\hline Males & 30 & & & 31.6 & & & $0.36 \ddagger$ \\
\hline Post-traumatic OA & 7.7 & & & 6.2 & & & $0.22 \ddagger$ \\
\hline Rheumatic arthritis & 4.7 & & & 4 & & & $0.47 \ddagger$ \\
\hline Diabetes mellitus & 21.3 & & & 24.8 & & & $0.134 \ddagger$ \\
\hline
\end{tabular}

MB: Group of mobile-bearing total knee replacement; FB: Group of fixed-bearing total knee replacement; BMI: Body mass index; OA: Osteoarthritis; ${ }^{\star}$ T-test; † Mann-Whitney U test; $\ddagger$ Chi-square test.

the analysis. Frequency data were judged using the chi-squared test.

The Kaplan-Meier curve was used to statistically evaluate the survival of TKR. The method was adapted to calculate the cumulative probability of survival of TKR over the 15-year period with a 95\% confidence interval (CI). Revision of knee replacement was considered the endpoint. If a revision was not recorded at the end of the follow-up period, the time from the operation to the last check was reported as censored.

When assessing the risk of the revision, the results were interpreted as a RR, with a $95 \%$ CI. To assess the significance level (p), the chi-square test was used. Relative risk is the ratio of risks in individual evaluated groups. If the RR is less than one, it means that the risk in the evaluated group is less than the risk in the control group. The control group was the group of FB TKRs.

The results of multivariate logistic regression analysis were reported as odds ratio for revision, with a 95\% CI and a corresponding significance level (p).

The level for statistical significance was set at $\mathrm{p}<0.05$ for all tests. SigmaPlot version 12.5 (Systat Software Inc., San Jose, USA) was used for statistical analyses.

\section{RESULTS}

No statistically significant differences were found in the population without revision surgery between

TABLE II

Demographics of all revised total knee replacements

\begin{tabular}{|c|c|c|c|c|c|c|c|}
\hline & \multicolumn{3}{|c|}{ MB $(n=32)$} & \multicolumn{3}{|c|}{$\mathrm{FB}(\mathrm{n}=31)$} & \multirow[b]{2}{*}{$p$} \\
\hline & $\%$ & Mean & Range & $\%$ & Mean & Range & \\
\hline Time to revision (month) & & 37.3 & $0.4-175.7$ & & 86.4 & $0.5-222.6$ & $<0.001^{*}$ \\
\hline $\begin{array}{l}\text { Age of patients in time of } \\
\text { primary TKR (year) }\end{array}$ & & 65.2 & $45.3-80.3$ & & 63.5 & $46.5-81.4$ & $0.47 \dagger$ \\
\hline $\begin{array}{l}\text { Age of patients in time of } \\
\text { revision of TKR (year) }\end{array}$ & & 68.4 & $46.5-83.3$ & & 70.9 & $53.8-85.5$ & $0.27 \dagger$ \\
\hline BMI of patients $\left(\mathrm{kg} / \mathrm{m}^{2}\right)$ & & 31.8 & $22.0-43.5$ & & 29.7 & $21.6-44.6$ & $0.046 \dagger$ \\
\hline Males & 22 & & & 51.6 & & & $0.015 \ddagger$ \\
\hline Post-traumatic OA & 25 & & & 13 & & & $0.23 \ddagger$ \\
\hline Rheumatic arthritis & 3.1 & & & 0 & & & $0.34 \ddagger$ \\
\hline Diabetes mellitus & 32.3 & & & 29 & & & $0.86 \ddagger$ \\
\hline
\end{tabular}

MB: Group of mobile-bearing total knee replacement; FB: Group of fixed-bearing total knee replacement; BMI: Body mass index; OA: Osteoarthritis; ${ }^{*}$ Mann-Whitney Test; † T-test; $\ddagger$ Chi-square test. 

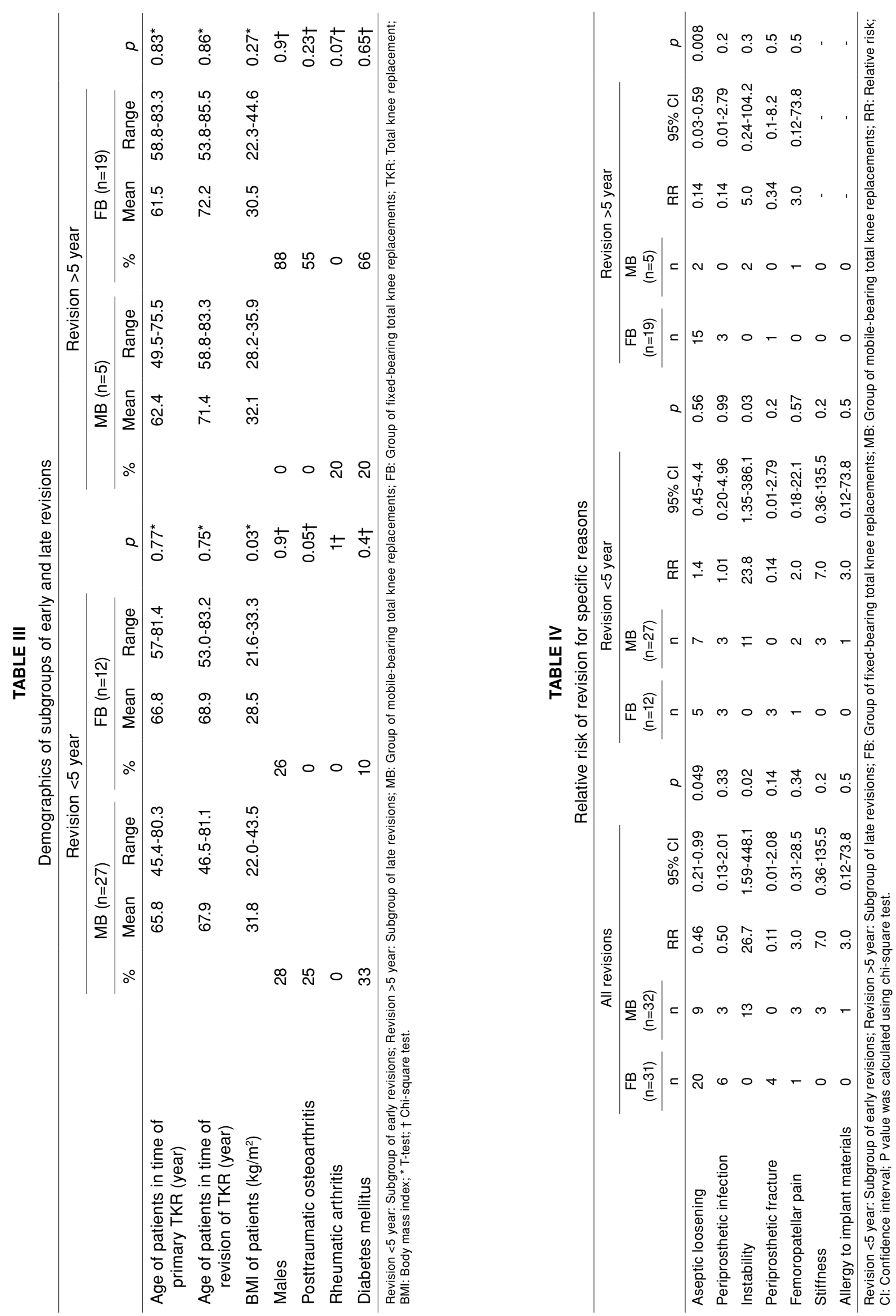
FB and MB groups with respect to the duration of follow-up, average age, gender and patients' BMI or the occurrence of post-traumatic OA and associated disorders (Table I).

In the population with revised TKRs, a significantly shorter time to revision $(\mathrm{p}<0.001)$ was observed with MB (37.3 months; range, 0.4-175.7) than with FB (86.4 months; range, 0.5-222.6), a significantly higher BMI $(\mathrm{p}=0.046)$ of patients with MB (31.8 kg/m²; range, 22.0-43.5) than with FB $\left(39.7 \mathrm{~kg} / \mathrm{m}^{2}\right.$; range, 21.6-44.6) and lower percentage of males in the group of MB TKRs (MB: $22 \%$, FB: $51.6 \%$; $\mathrm{p}=0.015$; Table II). Significantly higher BMI $(\mathrm{p}=0.03)$ was also found in the subgroup of early revision of TKRs with MB $\left(31.8 \mathrm{~kg} / \mathrm{m}^{2}\right.$; range, $\left.22.0-43.5\right)$ than with FB $\left(28.5 \mathrm{~kg} / \mathrm{m}^{2}\right.$; range, 21.6-33.3; Table III).

Surgical revision was performed in a total of 32 implanted MB TKRs and in 31 FB TKRs. Of this number, early revisions were performed in 27 mobile knees and in 12 fixed knees. Late revisions were more frequent in the FB group ( $n=19$ vs. $n=5$ ). The number of revisions for specific reasons is listed in Table IV.

No statistically significant difference was found between FB and MB TKRs regarding the RR of total revision for any reasons. In the subgroup of early revisions for any reasons, 2.22-fold increased risk of revision was found in the MB group (RR 2:22; 95\% CI: 1.13-4.35; $\mathrm{p}=0.02$ ). However, the risk of late revisions for any reason in MB TKRs was 73\% lower than the risk in FB TKRs (RR 0.27; 95\% CI: 0.1-0.72; $\mathrm{p}=0.009$; Table V).

When analyzing the risk of revisions for specific reasons, significantly higher risk of revision for instability was found in the subgroup of early revisions in MB TKRs (RR 23.8; 95\% CI: 1.35-386.1; $\mathrm{p}=0.03$ ). This risk was also apparent in the total revision subgroup (RR 26.7; 95\% CI: 1.59-448.1; $\mathrm{p}=0.02$ ). On the other hand, mobile inserts in TKRs were associated with significantly lower risk of total (RR 0.46; 95\% CI: 0.21-0.99; $\mathrm{p}=0.049)$ and late revisions due to aseptic loosening (RR 0.14; 95\% CI: 0.03-0.59; $\mathrm{p}=0.008$; Table IV).

The 15-year Kaplan-Meier survival estimates showed survival at 95\% for MB TKRs and 93\% for FB TKRs with revision defined as the end-point (Figure 1). The difference was not statistically significant $(\mathrm{p}=0.604)$.

Logistic regression analysis confirmed that the strongest independent negative prediction factors for revision of TKR for the entire observation period were the patient's age being lower than 55 years

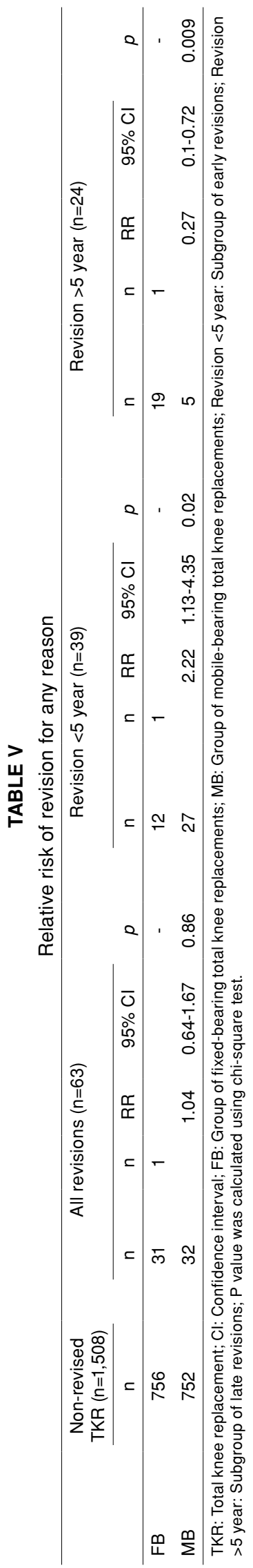




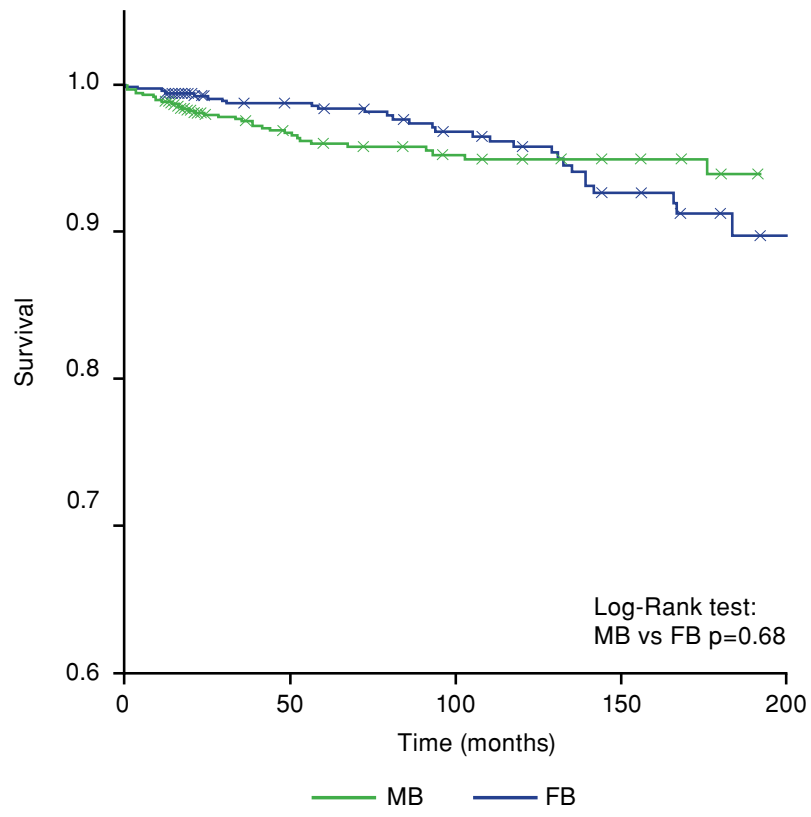

Figure 1. Fifteen-year Kaplan-Meier curves showed $95 \%$ survival rate of mobile-bearing total knee replacements and $93 \%$ survival rate of fixed-bearing total knee replacements.

MB: Group of mobile-bearing total knee replacement; FB: Group of fixed-bearing total knee replacement; $\mathrm{x}$ : Censored data.

(OR 4.421; 95\% CI: 2.179-8.968; $\mathrm{p}<0.001)$ and BMI being over $40 \mathrm{~kg} / \mathrm{m}^{2}$ (OR 3.275; 95\% CI: 1.07-10.024; $\mathrm{p}=0.038$ ). Other independent variables, including the type of bearing insert, failed to reach the level of statistical significance (Table VI).

In the multivariate logistic regression analysis for the subgroup of early revisions, BMI higher than $40 \mathrm{~kg} / \mathrm{m}^{2}$ (OR 5.471; 95\% CI: 1.736-17.247; $\mathrm{p}=0.004$ ), post-traumatic arthritis (OR 2.572; 95\% CI: 1.05-6.3; $\mathrm{p}=0.039$ ) and the use of $\mathrm{MB}$ insert (OR 2.484; 95\%
CI: $1.217-5.071 ; p=0.012)$ were identified as negative predictors of early revision (Table VII).

In the subsequent multi-variate logistic regression analysis for the subgroup of late revisions, single negative predictor of revision was confirmed. This was the age being lower than 55 years (OR 5.601; 95\% CI: 1.961-16.004; $\mathrm{p}=0.001)$. The use of MB insert has been shown as the protective factor (OR $0.262 ; 95 \%$ CI: 0.0965-0.713; $\mathrm{p}=0.001$; Table VIII).

\section{DISCUSSION}

During the entire observation period between 2002 and 2018, we have found no statistically significant differences in cumulative survival or in the total risk of surgical revision for any reason between the group of $784 \mathrm{MB}$ and 787 FB TKRs. We found a statistically significantly higher risk of early revisions when mobile insert was used in TKRs. However, in group of late revisions, the use of mobile inserts in TKRs has been shown to be a significant protective factor. The most significant effect of the type of bearing insert was found in revisions due to aseptic loosening and instability. In revisions for other reasons, we failed to find differences in the risk of revision.

The term "mobile bearing" is referred to various designs, differing in their mobility: rotating-platform designs allow for free rotation of polyethylene insert around central axis of the tibia, meniscal-bearing designs allow unconstrained movement of the insert, and rotating/translating designs allow for gliding in anterior-posterior plane and some rotation around the central axis of the tibia.

Because of the motion at tibia-insert interface, MB TKRs can achieve movement more similar to

TABLE VI

Multiple logistic regression of independent predictors of total knee replacement revisions for entire follow-up period

\begin{tabular}{|c|c|c|c|c|c|c|c|c|}
\hline Independent variable & Coefficient & SE & $\begin{array}{c}\text { Wald } \\
\text { statistic }\end{array}$ & $p$ & $\begin{array}{c}\text { Variable } \\
\text { inflation } \\
\text { factor }\end{array}$ & OR & $5 \% \mathrm{CL}$ & $95 \% \mathrm{CU}$ \\
\hline Constant & -3.602 & 0.24 & 225.457 & $<0.001$ & & 0.0273 & 0.017 & 0.0437 \\
\hline Age under (55 years) & 1.486 & 0.361 & 16.963 & $<0.001$ & 1.048 & 4.421 & 2.179 & 8.968 \\
\hline Male & 0.182 & 0.281 & 0.419 & 0.517 & 1.045 & 1.199 & 0.692 & 2.079 \\
\hline Body mass index over $\left(40 \mathrm{~kg} / \mathrm{m}^{2}\right)$ & 1.186 & 0.571 & 4.322 & 0.038 & 1.005 & 3.275 & 1.07 & 10.024 \\
\hline Post-traumatic osteoarthritis & 0.706 & 0.376 & 3.529 & 0.06 & 1.087 & 2.026 & 0.97 & 4.233 \\
\hline Rheumatic arthritis & -1.042 & 1.026 & 1.03 & 0.31 & 1.01 & 0.353 & 0.0472 & 2.638 \\
\hline Diabetes mellitus & 0.331 & 0.288 & 1.321 & 0.25 & 1.009 & 1.392 & 0.792 & 2.446 \\
\hline Mobile-bearing platform & 0.0436 & 0.263 & 0.0275 & 0.868 & 1.006 & 1.045 & 0.624 & 1.749 \\
\hline
\end{tabular}


TABLE VII

Multiple logistic regression of independent predictors of early total knee replacement revisions

\begin{tabular}{|c|c|c|c|c|c|c|c|c|}
\hline Independent variable & Coefficient & SE & $\begin{array}{c}\text { Wald } \\
\text { statistic }\end{array}$ & $p$ & $\begin{array}{c}\text { Variable } \\
\text { inflation } \\
\text { factor }\end{array}$ & OR & $5 \% \mathrm{CL}$ & $95 \% \mathrm{CU}$ \\
\hline Constant & -4.531 & $3.56 \mathrm{E}-01$ & 161.822 & $<0.001$ & & 0.0108 & 0.00536 & 0.0216 \\
\hline Age under (55 years) & 0.979 & 0.507 & 3.723 & 0.054 & 1.047 & 2.661 & 0.985 & 7.193 \\
\hline Male & 0.0312 & 0.36 & 0.00751 & 0.931 & 1.047 & 1.032 & 0.51 & 2.088 \\
\hline Body mass index over $\left(40 \mathrm{~kg} / \mathrm{m}^{2}\right)$ & 1.699 & 0.586 & 8.416 & 0.004 & 1.006 & 5.471 & 1.736 & 17.247 \\
\hline Post-traumatic osteoarthritis & 0.945 & 4.57E-01 & 4.273 & 0.039 & 1.087 & 2.572 & 1.05 & 6.3 \\
\hline Rheumatic arthritis & -14.514 & 1083.695 & 0.000179 & 0.989 & 1.009 & 4.97E-07 & 0 & (+inf) \\
\hline Diabetes mellitus & 0.27 & 3.68E-01 & 0.539 & 0.463 & 1.008 & 1.31 & 0.637 & 2.695 \\
\hline Mobile-bearing platform & 0.91 & 0.364 & 6.242 & 0.012 & 1.007 & 2.484 & 1.217 & 5.071 \\
\hline
\end{tabular}

SE: Standard error; OR: Odds ratio; CL: Confidence lower; CU: Confidence upper.

TABLE VIII

Multiple logistic regression of independent predictors of late total knee replacement revisions

\begin{tabular}{lccccccccc}
\hline Independent variable & Coefficient & SE & $\begin{array}{c}\text { Wald } \\
\text { statistic }\end{array}$ & $p$ & $\begin{array}{c}\text { Variable } \\
\text { inflation } \\
\text { factor }\end{array}$ & OR & $5 \% \mathrm{CL} 95 \% \mathrm{CU}$ \\
\hline Constant & & & & & & 0.0168 & 0.00879 & 0.0322 \\
Age under (55 years) & -4.085 & 0.331 & 152.228 & $<0.001$ & & 5.601 & 1.961 & 16.004 \\
Male & 1.723 & 0.536 & 10.349 & 0.001 & 1.039 & 0.938 & 0.376 & 2.342 \\
Body mass index over (40 kg/m $\left.\mathrm{m}^{2}\right)$ & 1.132 & 1.058 & 1.145 & 0.285 & 1.007 & 3.102 & 0.39 & 24.675 \\
Post-traumatic osteoarthritis & 0.892 & 0.592 & 2.271 & 0.132 & 1.082 & 2.44 & 0.765 & 7.784 \\
Rheumatic arthritis & 0.111 & 1.055 & 0.0111 & 0.916 & 1.01 & 1.118 & 0.141 & 8.846 \\
Diabetes mellitus & 0.26 & 0.466 & 0.312 & 0.577 & 1.01 & 1.297 & 0.521 & 3.23 \\
Mobile-bearing platform & -1.338 & 0.51 & 6.884 & 0.009 & 1.005 & 0.262 & 0.0965 & 0.713 \\
\hline
\end{tabular}

SE: Standard error; OR: Odds ratio; CL: Confidence lower; CU: Confidence upper.

the physiological knee kinematics. This motion also enables a certain degree of self-correction of the rotational mismatch between the implanted femoral and tibial component. ${ }^{[5]}$ This should improve patellar tracking and reduce anterior knee pain. Wyatt et al. ${ }^{[6]}$ actually detected lower risk of revision of MB TKRs due to more frequent secondary patellar resurfacing in cases of FB TKRs. This has not been confirmed in our study; $\mathrm{MB}$ knees were associated with higher risk of revision due to peripatellar pain, although the difference did not reach statistical significance.

Due to design of mobile inserts in TKR, greater tibiofemoral congruency can be achieved to reduce shear and tear forces and thereby reduce wear of polyethylene insert without increasing the stress at the bone-implant interface. ${ }^{[7]}$ Despite the movement of the mobile inserts on the tibial component, the FB prostheses demonstrate higher degree of polyethylene wear at the tibia-insert interface.$^{[8]}$ Fixed- bearing implants, in order to grant a suitable locking junction in the tibial component, are necessarily made of titanium alloy and thus, however well finished, unable to provide an ideal smooth surface for insert. Mobile-bearing tibial baseplates are usually made of a highly polished chromium-cobalt alloy instead. These properties of the MBs should thus hypothetically ensure lower risk of revisions due to excessive polyethylene wear and aseptic loosening of the implants. Our results confirm this hypothesis - MB TKRs demonstrated significantly lower risk of revision for aseptic loosening. To our knowledge, no similar results have been published. Most studies have reported no differences, some authors point to even higher risk of aseptic loosening of mobile knees. Gothesen et al. ${ }^{[1]}$ analyzed the Norwegian and Australian arthroplasty registers of implanted TKRs in the period of 2003 through 2014 and found significantly higher risk of revisions due to aseptic 
loosening for MB prostheses. Namba et al. ${ }^{[3]}$ published similar results based on the analysis of six national arthroplasty registers for the period of 2001 through 2010. Mobile inserts were identified as a significant risk factors for revision of TKRs, mainly due to their aseptic loosening. The possible explanation of the discrepancy between our results and the published results may be in the inclusion of other models of prostheses in the evaluated sets. In the said analyses, the MB TKRs most commonly included the Low Contact Stress MB implant (LCS ${ }^{\circledR}$, DePuy, Synthes, Raynham, Massachusetts, USA), which was not found in our set. Several authors pointed out a significantly higher degree of revisions of this implant when compared to other implants..$^{[9-12]}$ This was explained by the design of the tibial component (low surface roughness of the lower tibial baseplate, non-keeled stem), which, in combination with thin cement layer and with non-optimal axial alignment, lead to a significantly higher rate of aseptic loosening of the tibial component.

The use of MB implants is associated with a higher risk of instability of arthroplasty with possible subluxation or luxation of the insert. ${ }^{[5]}$ This is usually a consequence of improper surgical technique, such malposition of components, extensive posterolateral release, extension and flexion gap imbalance, increased flexion instability, or extensor mechanism dysfunction. ${ }^{[13]}$ In our study, the revisions due to instability were clearly associated with mobile bearings as all cases were recorded in the group of MB TKRs. Most of these revisions (11 out of 13) were performed in the period within five years from the primary surgery, which was reflected in significantly greater risk of early revisions due to any reason in the group of MB implants. Also, Graves et al. ${ }^{[2]}$ found a greater risk of early revisions with $\mathrm{MB}$ endoprostheses. The statistically significant difference was found only in the first year after the primary implantation.

Another factor that could also contribute to higher risk of early revisions of $\mathrm{MB}$ implants in our study was a significantly higher BMI in patients with this type of prosthesis. Severe obesity (BMI over $\left.40 \mathrm{~kg} / \mathrm{m}^{2}\right)$ is a major risk factor of knee prosthesis failure. ${ }^{[14]}$ We clearly confirmed the co-incidence of BMI over $40 \mathrm{~kg} / \mathrm{m}^{2}$ and MB inserts in TKR as negative predictors of revisions by multivariate logistic regression analysis.

Based on meta-analysis of previously published studies, no differences were found in the clinical outcomes, overall survival or revision rate between $\mathrm{FB}$ and MB TKRs. ${ }^{[5,15,16]}$ Also in our study, we detected no differences in the cumulative survival rate and total risk of revisions for any reason. This was the result of a higher rate of early revisions due to instability and on the contrary, a lower revision rate due to aseptic loosening in the group of MB knees. We suppose that reducing the number of revisions for instability with a more exacting surgical technique and excluding severe obese patients should secure a greater survival rate of MB TKRs.

The limitation of this study based on the analysis of performed revisions of TKRs is the fact that it may not necessarily reflect the exact clinical results of joint replacements. Unfortunately, there are no records of patients who are not satisfied with the arthroplasty or who had failure of the prosthesis, but for various reasons never have surgical revision. Another limitation may be certain "inhomogeneity" of the evaluated group of TKRs. It included several models of prostheses and were implanted by several orthopedic surgeons with different levels of experience. However, cemented total knee prostheses were used in all cases preserving posterior cruciate ligament without primary patellar resurfacing. All TKRs were performed by the similar surgical technique, with the same postoperative protocol.

The strong aspects of the study are the length of the observation period, almost equal number of $\mathrm{MB}$ and FB TKRs in the evaluated groups, multi-variate logistic regression, considering several factors related to the revision, as well as the analysis of RR of revision from specific reasons.

In conclusion, we have found no difference in the cumulative survival rates between MB and FB TKRs. However, MB TKRs were associated with a lower risk of revision due to aseptic loosening in comparison with FB TKRs. Mobile-bearing inserts represented a significant risk factor only for early revisions due to instability.

\section{Declaration of conflicting interests}

The authors declared no conflicts of interest with respect to the authorship and/or publication of this article.

\section{Funding}

The authors received no financial support for the research and/or authorship of this article.

\section{REFERENCES}

1. Gothesen O, Lygre SHL, Lorimer M, Graves S, Furnes O. Increased risk of aseptic loosening for 43,525 rotatingplatform vs. fixed-bearing total knee replacements. Acta Orthop 2017;88:649-56.

2. Graves S, Sedrakyan A, Baste V, Gioe TJ, Namba R, Martínez Cruz $\mathrm{O}$, et al. International comparative evaluation of knee replacement with fixed or mobile-bearing posteriorstabilized prostheses. J Bone Joint Surg Am 2014;96:59-64. 
3. Namba R, Graves S, Robertsson O, Furnes O, Stea S, PuigVerdié $\mathrm{L}$, et al. International comparative evaluation of knee replacement with fixed or mobile non-posterior-stabilized implants. J Bone Joint Surg Am 2014;96:52-8.

4. Khan M, Osman K, Green G, Haddad FS. The epidemiology of failure in total knee arthroplasty: avoiding your next revision. Bone Joint J 2016;98:105-12.

5. Capella M, Dolfin M, Saccia F. Mobile bearing and fixed bearing total knee arthroplasty. Ann Transl Med 2016;4:127.

6. Wyatt MC, Frampton C, Horne JG, Devane P. Mobile- versus fixed-bearing modern total knee replacements- which is the more patella-friendly design?: The 11-year New Zealand Joint Registry study. Bone Joint Res 2013;2:129-31.

7. O'Connor JJ, Goodfellow JW. Theory and practice of meniscal knee replacement: designing against wear. Proc Inst Mech Eng H 1996;210:217-22.

8. Callaghan JJ, Insall JN, Greenwald AS, Dennis DA, Komistek RD, Murray DW, et al. Mobile-bearing knee replacement: concepts and results. Instr Course Lect 2001;50:431-49.

9. Gøthesen O, Espehaug B, Havelin L, Petursson G, Lygre $\mathrm{S}$, Ellison $\mathrm{P}$, et al. Survival rates and causes of revision in cemented primary total knee replacement: a report from the Norwegian Arthroplasty Register 1994-2009. Bone Joint J 2013;95:636-42.
10. Kutzner I, Hallan G, Høl PJ, Furnes O, Gøthesen Ø, Figved $\mathrm{W}$, et al. Early aseptic loosening of a mobile-bearing total knee replacement. Acta Orthop 2018;89:77-83.

11. Namba RS, Inacio MC, Paxton EW, Ake CF, Wang C, Gross $\mathrm{TP}$, et al. Risk of revision for fixed versus mobile-bearing primary total knee replacements. J Bone Joint Surg [Am] 2012;94:1929-35.

12. Paxton EW, Furnes $\mathrm{O}$, Namba RS, Inacio MC, Fenstad AM, Havelin LI. Comparison of the Norwegian knee arthroplasty register and a United States arthroplasty registry. J Bone Joint Surg [Am] 2011;93:20-30.

13. Bo ZD, Liao L, Zhao JM, Wei QJ, Ding XF, Yang B. Mobile bearing or fixed bearing? A meta-analysis of outcomes comparing mobile bearing and fixed bearing bilateral total knee replacements. Knee 2014;21:374-81.

14. Jasper LL, Jones CA, Mollins J, Pohar SL, Beaupre LA. Risk factors for revision of total knee arthroplasty: a scoping review. BMC Musculoskelet Disord 2016;17:182.

15. Moskal JT, Capps SG. Rotating-platform TKA no different from fixed-bearing TKA regarding survivorship or performance: a meta-analysis. Clin Orthop Relat Res 2014;472:2185-93.

16. Fransen BL, van Duijvenbode DC, Hoozemans MJM, Burger BJ. No differences between fixed- and mobile-bearing total knee arthroplasty. Knee Surg Sports Traumatol Arthrosc 2017;25:1757-77. 